Bangladesh J. Sci. Res. 30(1\&2): 1-9, 2017 (December)

\title{
PETROLEUM SYSTEM OF SRIKAIL GAS FIELD USING SEQUENCE STRATIGRAPHY
}

\author{
Md. Imam Sohel Hossain, A.S.M. Woobaidullah* and Md. Jamilur Rahman ${ }^{1}$ \\ Department of Geology, University of Dhaka, Dhaka-1000, Bangladesh
}

\begin{abstract}
A sequence stratigraphic analysis was carried out on the sedimentary packages of parts of the Bengal Basin hydrocarbon province. This paper focuses on the identification of petroleum system of Srikail Gas Field within eastern folded belt of Bengal basin using sequence stratigraphic concept. Three strike and five dip seismic lines are used in this work and data analysis is done using Petrel 2015 software. Seismic line-2 (SK-2) of Srikail is good in resolution and is used here only for identifying potential petroleum system. Seven sequence boundaries were identified on the basis of onlap and reflection truncation. The result of the interpreted sequence boundary has revealed that all the elements which are required to generate a potential prospect are present in the study area. Fine grained sediments deposited during the rising and lowering of sea level might act as a potential source rock. Time contour maps of the study area have revealed that the NWSE trending anticlinal Srikail structure is largely affected by shale filled channel in the crestal and western flank. The channel filled shale is later acting as a seal on north and western part of the structure. Erosional remnants truncated against shale fill canyon is acting as prospective reservoirs in the Srikail gas field. The NW-SE trending anticlinal structure and shale fill canyon help this sand as potential traps for hydrocarbon accumulation. Hence the petroleum system of the study area become very prospective in terms of hydrocarbon accumulation.
\end{abstract}

Key words: Sequence boundary, Erosional remnants, Incised valley, Reservoir, Trap and seal

\section{Introduction}

Bangladesh is going to face energy shortage in the sector of fossil fuel. From the estimated energy reserves and the future energy demand, it appears that the country may not be able to attain longterm energy security based on its own reserves, but it could well achieve a better energy situation for the present and near future if the available resources could be better exploited (Imam 2005).

Further, the identification of petroleum system of any gas field is very important as conventional petroleum resources continue to diminish around the globe, exploration and production companies have little option but to produce and develop smaller and more complex reserves of which it is believed that there are good prospects in the Bengal delta. Sequence stratigraphy, which is applied in this study is a highly successful in the exploration and production of petroleum and mineral resources. The concept of sequence stratigraphy was initiated and developed through seismic stratigraphy as a methodology for stratigraphic interpretation.

*Author for correspondence: <woobaid.du@gmail.com>. ${ }^{1}$ Chevron Bangladesh. 
Sequence stratigraphy helps to identify the suitable spot of drilling by its potential to predict facies within a chronostratigraphically constrained framework of unconformity-bound depositional sequences. It provides the potential for chronostratigraphic correlation within and among growthfaulted sub-basins, thus improving prediction of stratigraphic and areal distribution of deeply buried lowstand reservoirs. Sequence stratigraphy provides a guide to potential combination traps and the opening of a window on exploration for deep, unexpanded sub-fault reservoirs and traps, thereby enabling explorationists to properly place a given sub-basin into a petroleum system framework in a cost-effective manner (Vail and Wornardt 1991).

The aim of this study is to identify the petroleum system using seismic stratigraphic concept in Srikail gas field within north-eastern parts of the folded-belt of the Bengal Basin with a view to identifying source rock, reservoir, trap, seal and migration path. The objectives of this work are to determine the major chronostratigraphic surfaces and units in the study area, using the available seismic data and identify sequence boundary associated with potential hydrocarbon in order to reduce the overall exploration risk.

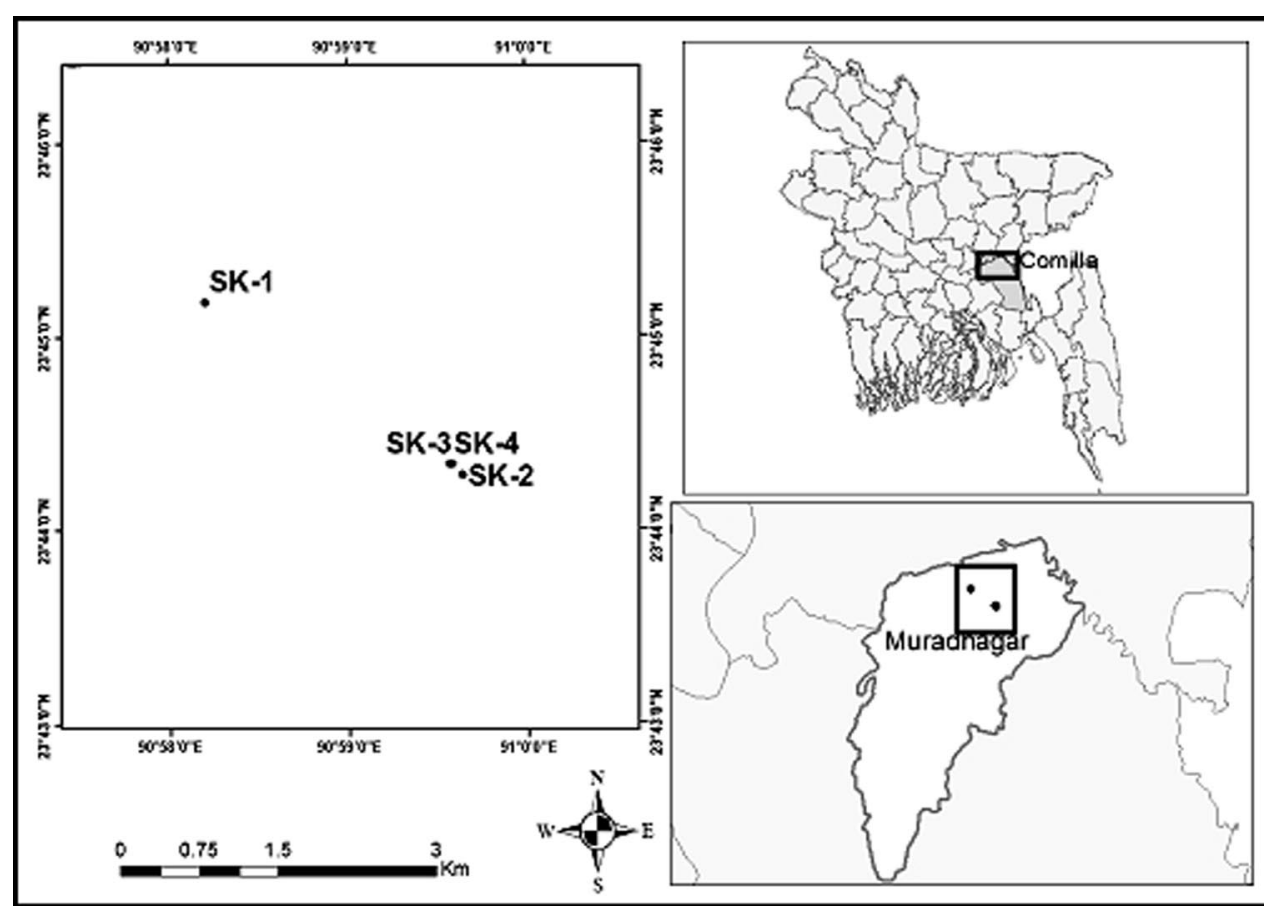

Fig. 1. Location map of the study area.

The study area: Tectonically Srikail is located on the western part of folded belt of Bengal Foredeep within Tripura Uplift of the Bengal Basin (Khan 1991). The basin is located in the northeastern part of India. It forms a part of Arakan-Assam Frontal Belt characterized by a number of $\mathrm{N}-\mathrm{S}$ tending long narrow elongated anticlines and broad flat intervening synclines occurring in 
enechelon fashion (Reimann 1993). The general trend of the major anticlines of this basin is NWSE with slight convexity towards the west. The intensity of folding increases towards east with progressively older rocks being exposed in the core of the anticline. Each anticline is generally bounded by longitudinal reverse faults on one or both flanks. During Cenozoic period huge sediments were deposited into the fold belt area. This area lies between the Indian plate in the west and Burmese plate in the east. In the northwest it abuts against the Shillong plateau and in the northeast it wedges towards Himalayan arc. It is filled mainly by orogenic sediments derived from the eastern Himalayas to the north and the Indo-Burma ranges to the east (Alam et al. 2003).

Srikail is surrounded by few anticlinal structures like Bakrabad to the south-west, Lalmai and Bangora to the south, and Titas to the north-east (Petrobangla Report 2009). The studied area is located in Muradnagar Upazilla of Comilla district under Chittagong Division. Srikail structure is located about 35 kilometer north-west of Comilla. It lies in the central part of petroleum Block-9, approximately 60 kilometers east of Dhaka city (Fig. 1) (BAPEX Report 2009).

\section{Materials and Methods}

Seismic data are used in this work and the data analysis is done using Petrel 2015 Software. Three strike lines and five dip lines of 2D seismic data are used (Figs 2 and 3). The seismic data analysis are done by the following procedure (Van Wagoner et al. 1988):

1. Mis-tie correction which includes seismic to seismic tie using bulk time shift and seismic to well tie

2. Sequence analysis

3. Selecting reflectors

4. Picking horizons

5. Synthetic seismogram preparation

6. Data integration

Mis-ties commonly occur when data of different phases, rather than uniformly zerophase data, are interpreted together, or data that have different data corrections are tied (Badley 1985). Mis-ties are corrected by seismic to seismic tie using bulk time shift and seismic to well tie in this work. Followed by the mis-tie correction, horizon interpretation work started. A horizon is an event, a reflection, in the seismic data. It is the goal of seismic interpretation. Horizons are picked using well tops guidance.

Seismic sequence analysis defines the genetic reflection packages referred to as seismic sequences and seismic systems tracts by identifying discontinuities on the basis of reflection termination patterns. Two patterns, onlap and downlap, occur above the discontinuity; three patterns, truncation, toplap, and apparent truncation, occur below the discontinuity. Sequence boundaries are characterized by regional onlap and truncation (Najman 2012). Sequence analysis is done in this work to identify the potential petroleum system. 


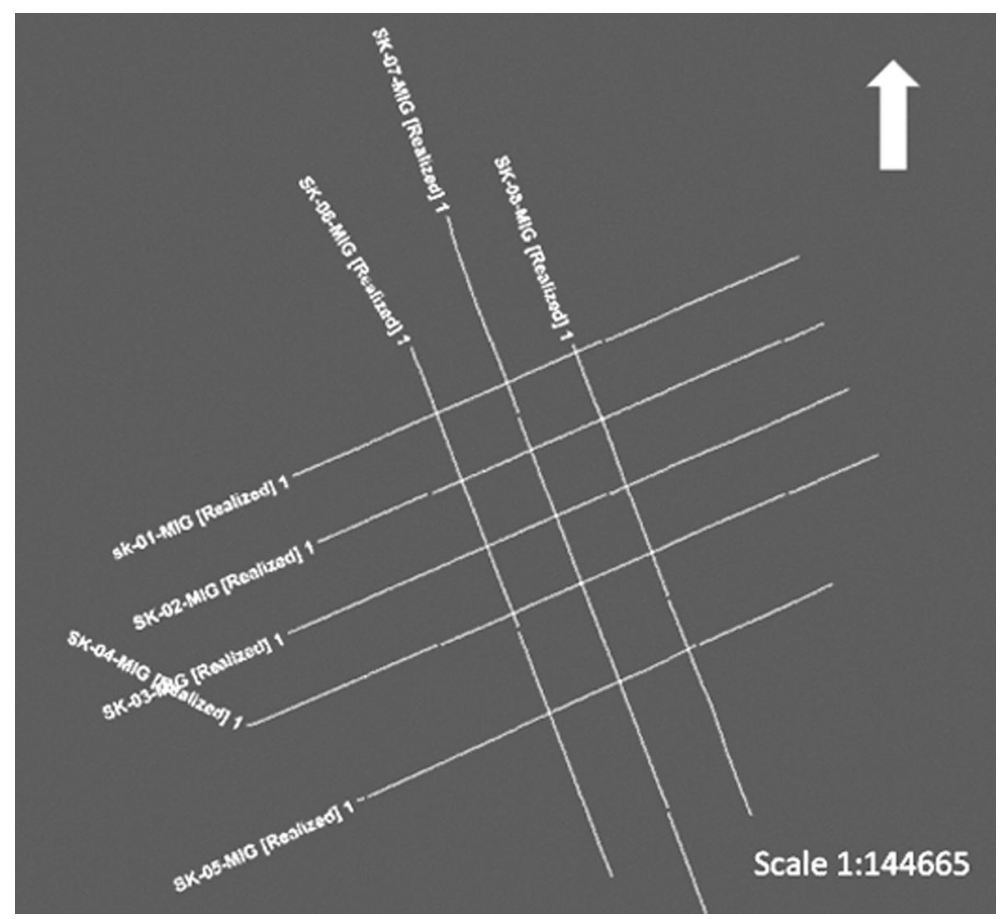

Fig. 2. 2D view of seismic layout.

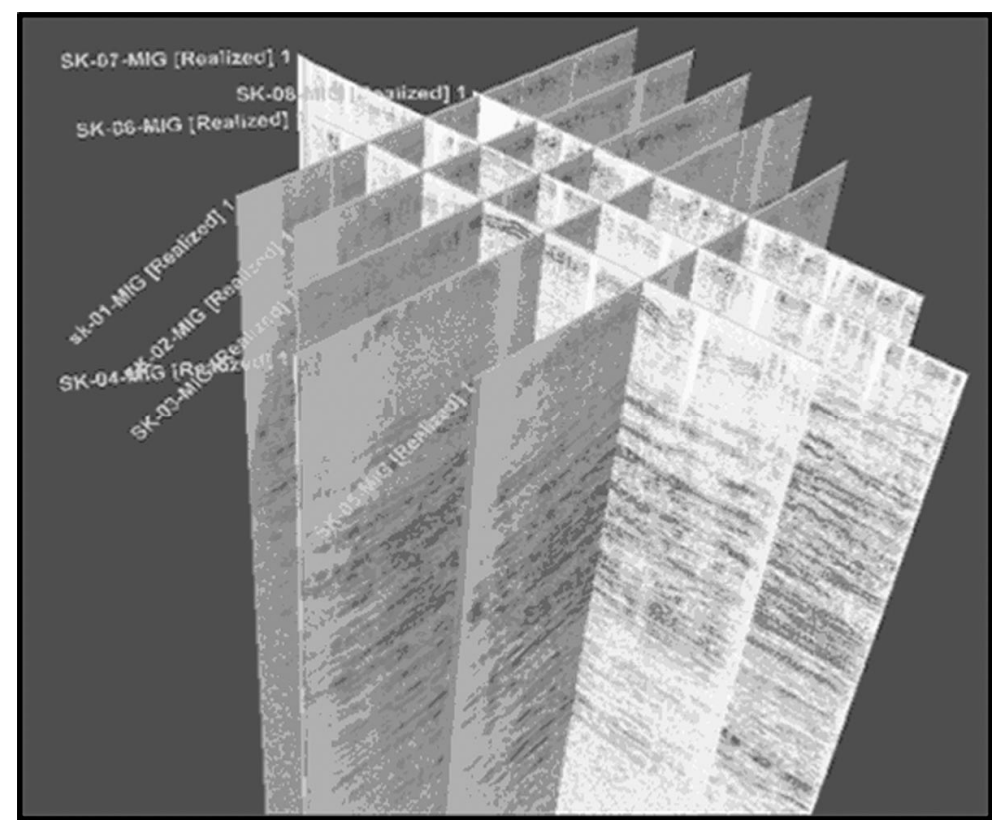

Fig. 3. 3D view of 2D seismic line. 
After completion of seismic interpretation time surfaces were generated and were used to identify reservoirs and seal rock as well as trapping mechanism (Keary and Brooks 1984).

\section{Results and Discussion}

Evaluating and identifying sequence boundary is based on the ability of the interpreter to make use of available information in interpreting the key horizons used for better visualization and interpreting the prospects of the study area. Seven sequence boundaries (SB) are identified based on sequence stratigraphic concept from the seismic line SK-2 of Srikail (Fig. 4) as it has better resolution than the others.

Every sequence boundary is related to the sea level change which indicates the cyclic transgression-regression regime (Coe 2002, Mitchum 1977). Sequence boundaries (SB) of the study area are distinct seismically mappable units (Fig. 4) bounded by prominent regional unconformities or their correlative conformities. The seismic facies are calibrated to lithostratigraphic units by well penetrations.

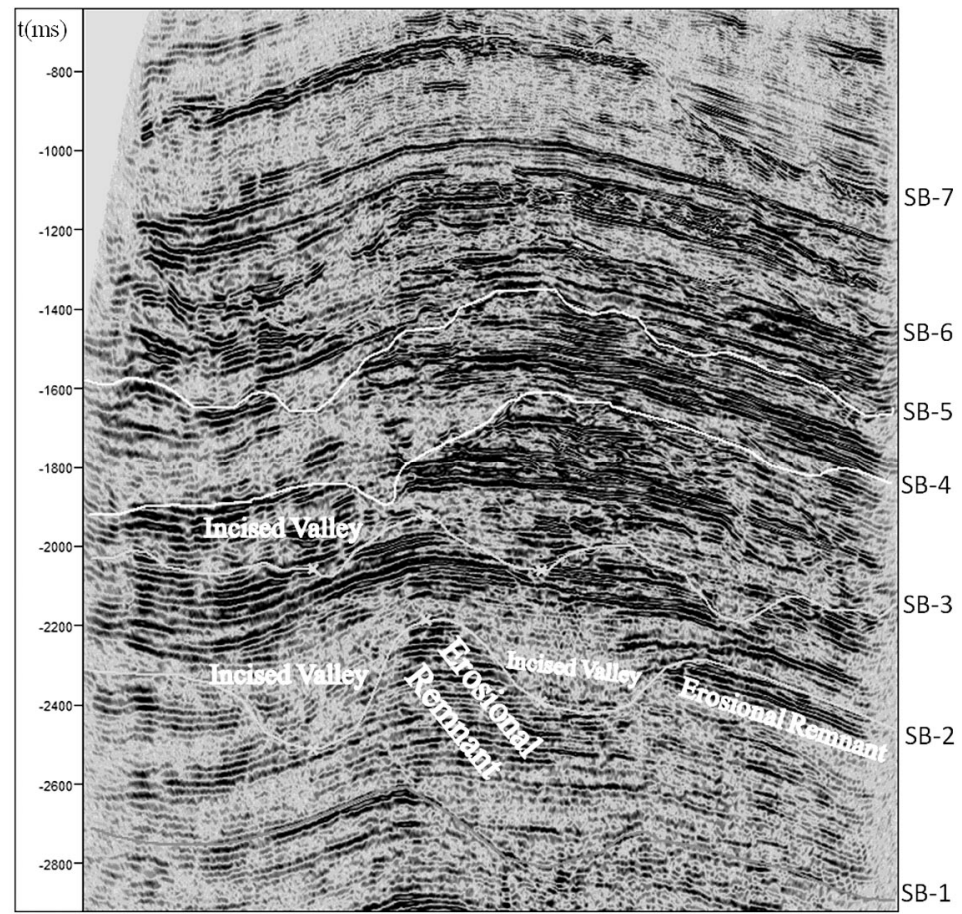

Fig. 4. Sequence boundary (SB) and incised valley are shown in seismic section of SK-2 of Srikail gas field.

Lower sequence boundaries (SB-1-3) are characterized by discontinuous geological outliers (sequence remnants) preserved between large, multiple, down cutting, infilled submarine canyons that incise into sequence boundaries below with considerable relief. The repeated cut and fill 
indicates fluctuating relative sea levels during the sequence deposition, superimposed on an overall relative sea level rise which allowed fills to be preserved and topsets to be stacked. On the other hand upper sequence boundaries (SB-4-7) are characterized by a return to a package of laterally continuous seismic reflectors and an absence of canyons (Fig. 4).

Among seven sequence boundaries two of them (SB-2 and SB-3) are identified to characterize the potential petroleum system for the study area and their time contour maps are generated. The time contours of SB-2 (Fig. 6) reveal that the NW-SE trending Srikail structure is largely affected in its crestal and western flank by incised channel during its course from north-eastern (shallow channel cut) and north-western (deep channel cut) parts of Srikail structure. The channel course is towards down dip from the northern part of the structure. The two distributor channels are coalesced in the southern part of the structure and continued its path towards the south.

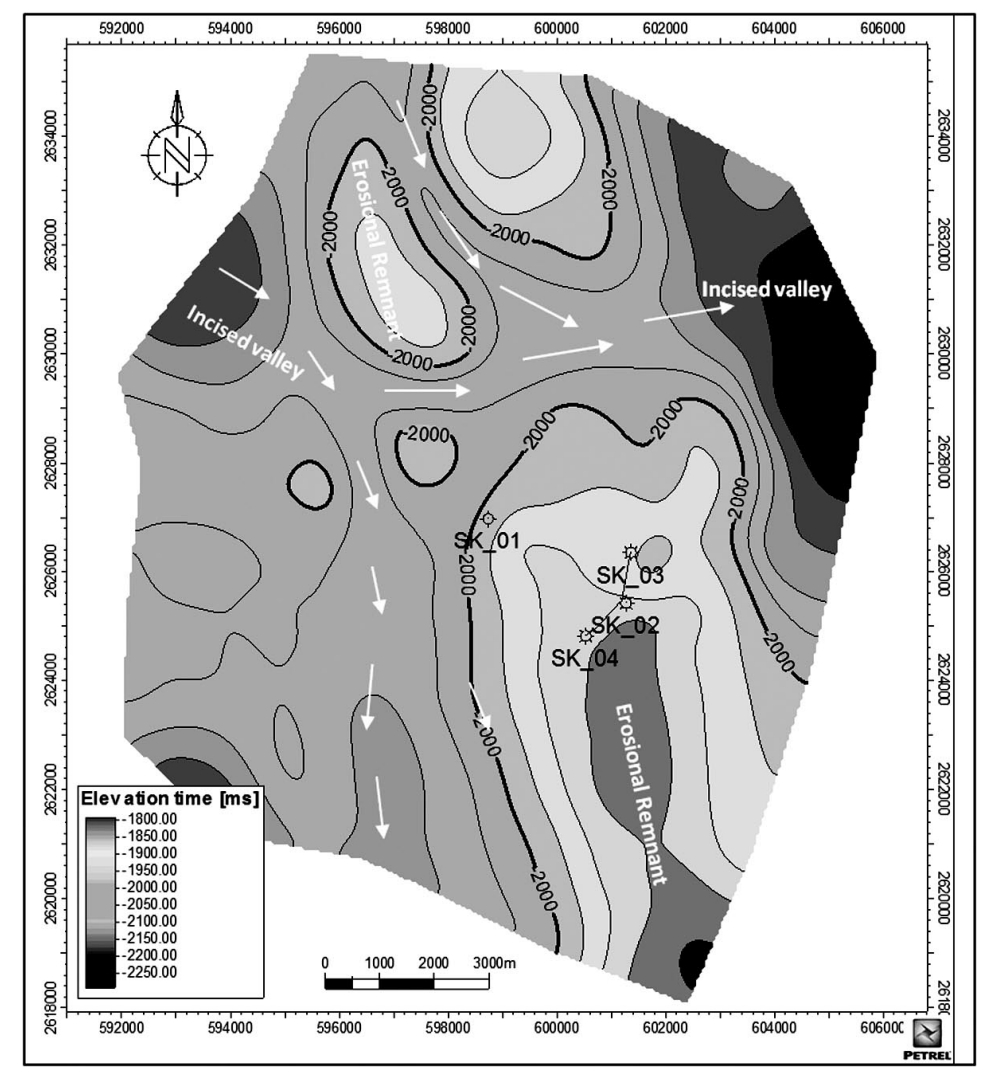

Fig. 5. Time contours map of sequence boundary 3 (SB-3).

The time contours of SB-3 (Fig. 5) reveal that the structure is similarly washed away by incised channel which divided the structure into three blocks. But the impact of erosion is less than the SB-2 because of higher position of sea level during the deposition of this sequence boundary.

The channel course is towards down dip from the northern part of the structure. During its 
course it is split into branches and consequently eroded the structure. Subsequently three potential sections in the crestal part of the structure preserved as an erosional remnant which is recognized by the high peak. The intensity of erosion in lower sequence boundary (SB-2) is much higher than the upper sequence boundary (SB-3) because of much lower position of sea level during the deposition of lower sequence boundary.

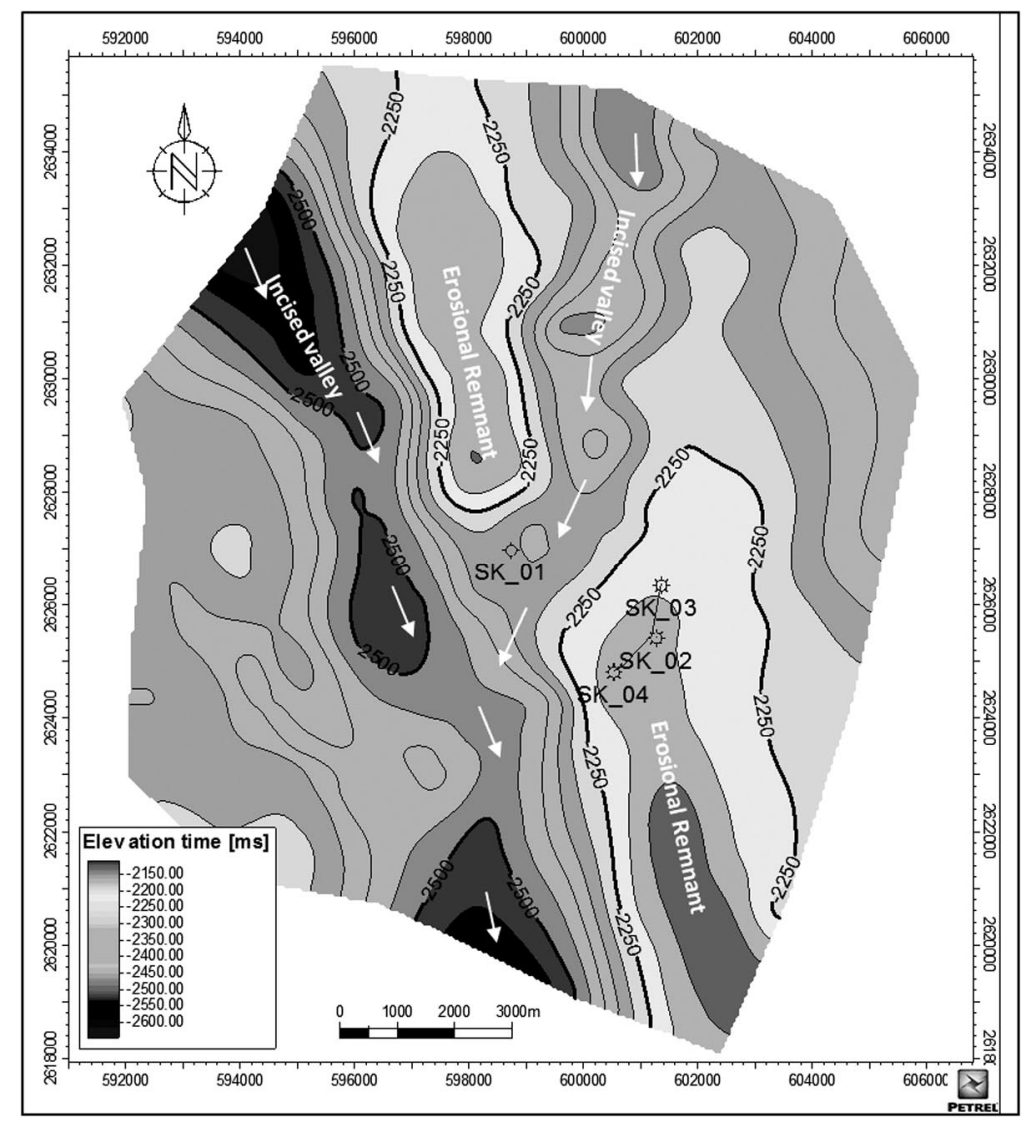

Fig. 6. Time contours map of sequence boundary 2 (SB-2).

From seismic sequence stratigraphy it is not confidently identified the source rock potential as seismic resolution is not quite sufficient. In general, the presence of source rock is proved due to the gas discovery in nearby Bakrabad and Saldanadi structure. Organic rich shale of Jenam Formation and lower Miocene Bhuban formation are suggested to be gas source rock potential for the study area (Imam 2005).

The sequence boundary is characterized by the truncation of the reflectors by incised valley erosion (Figs 4-6). The incised valley erosion is recognized by their poor reflectivity due to energy loss and broken reflections. From seismic time section it is seen that the erosional remnant of 
sediments recognized from high peak are playing as reservoirs preserved between infilled incised submarine canyonsin the Srikail gas field.

The channel filled shale identified by low amplitude reflectors is later acting as a seal on north and western part of the anticlinal structure. The NW-SE trending anticlinal structure and shale fill canyon is acting as potential traps for hydrocarbon accumulation.

No noticeable fault is delineated from the 2D seismic stratigraphic analysis. But there might be association of faults which are not recognized by the limited seismic resolution. So using 3D seismic high resolution data some fault might be identified and hence the path of migration could be known.

\section{Conclusion}

The results of interpreted sequence boundary have revealed that erosional remnant truncated against shale fill canyon is acting as prospective reservoirs in the Srikail gas field. The channel filled shale identified from low amplitude reflections is later acting as a seal in the study area. The NE-SW trending anticlinal structure and shale fill canyon is playing a crucial role of potential traps for hydrocarbon accumulation. Though the source rock and migration path are not confidently analyzed by this 2D low resolution data, reservoir with sealing and trapping system is easily identified by sequence stratigraphic analysis.

\section{Acknowledgements}

Authors highly acknowledge Bangladesh Petroleum Exploration and Production Company Limited (BAPEX) for providing data and Schlumberger, Bangladesh for providing software.

\section{References}

Alam, M., M.M. Alam, J.R. Curray, M.L.R. Chowdhury and M.R. Gani, 2003. An overview of the sedimentary geology of the Bengal Basin in relation to the regional tectonic framework and basin-fill history. Sedimentary Geology 155(3-4): 179-208.

Badley, E. M. 1985. Practical seismic interpretation. D. Reidel Publishing Company, Boston. p. 266.

BAPEX Report, November 2009. Srikail Geological Study.

Coe, A. L. (ed). 2002. The sedimentary record of sea-level change, Cambridge University Press.

Imam, B. 2005. Energy Resource of Bangladesh, University Grants Commission of Bangladesh, Dhaka. p. 280.

Keary, P. and M. Brooks 1984. An Introduction to Geophysical Exploration. Blackwell Scientific Publications, London, p. 296.

Khan, A. A. 1991. Tectonic of Bengal Basin. Journal of Himalayan Geol. 2(1): 91-101.

Mitchum Jr. R. M. 1977. Seismic Stratigraphy and Global Changes of Sea Level: Part 11. Glossary of Terms used in Seismic Stratigraphy: Section 2. Application of Seismic Reflection Configuration to Stratigraphic Interpretation, Memoir 26 Pages 205-212. 
Petroleum system of Srikail gas field using sequence stratigraphy

Najman, Y. 2012. The record of Himalayan erosion preserved in the sedimentary rocks of the Hatia Trough of the Bengal Basin and the Chittagong Hill Tracts, Bangladesh. Basin Research 24: 1-21.

Petrobangla, November 2009. Srikail Geological Study.

Reimann, K. U. 1993. Geology of Bangladesh, Gebriider-Brontraeger, Berlin, p. 160.

Vail, P.R. and W.W. Wornardt, 1991. An integrated approach to exploration and development in the 90's: well log-seismic sequence stratigraphy analysis, Gulf Coast: Association of Geological Society Transaction 41: 430-650.

Van Wagoner, J. C., H. W. Posamentier, R. M. J. Mitchum, P. R.Vail,J. F. Sarg, T. S. Loutit, and J. Hardenbol, 1988. An overview of the fundamentals of sequence stratigraphy and key definitions.

(Manuscript received on 7 August, 2017; revised on 22 February, 2018) 